\title{
Remembering An Abolitionist, Ambassador John R. Miller (May 23, 1938-October 4, 2017)
}

\author{
Eleanor Kennelly Gaetan \\ Frontline Reports Editor, Dignity, ekgaetan@gmail.com \\ Donna M. Hughes \\ Editor-in-Chief, Dignity, donnahughes@uri.edu
}

Follow this and additional works at: https://digitalcommons.uri.edu/dignity

Part of the American Studies Commons, Civil Rights and Discrimination Commons, Criminal Law Commons, Diplomatic History Commons, Feminist, Gender, and Sexuality Studies Commons, Human Rights Law Commons, International and Area Studies Commons, International Humanitarian Law Commons, International Law Commons, Labor History Commons, Law and Economics Commons, Law and Gender Commons, Law and Society Commons, Legal History Commons, Political History Commons, Public Affairs, Public Policy and Public Administration Commons, Rule of Law Commons, Social History Commons, Transnational Law Commons, and the United States History Commons

\section{Recommended Citation}

Gaetan, Eleanor Kennelly and Hughes, Donna M. (2017) "Remembering An Abolitionist, Ambassador John R. Miller (May 23, 1938-October 4, 2017)," Dignity: A Journal of Analysis of Exploitation and Violence: Vol. 2: Iss. 4, Article 11. https://doi.org/10.23860/dignity.2017.02.04.11

This Editorial is brought to you for free and open access by DigitalCommons@URI. It has been accepted for inclusion in Dignity: A Journal of Analysis of Exploitation and Violence by an authorized editor of DigitalCommons@URI. For more information, please contact digitalcommons-group@uri.edu. 


\title{
Remembering An Abolitionist, Ambassador John R. Miller (May 23, 1938-October $4,2017)$
}

\author{
Abstract \\ A memorial for Ambassador-at-Large to Monitor and Combat Trafficking in Persons, John R. Miller (May \\ 23, 1938-October 4, 2017). Ambassador Miller believed modern-day slavery, encompassing sex trafficking \\ and forced labor, requires a principled global offensive that the United States is morally obligated to lead. \\ In the four formative years he led the State Department's Office to Monitor and Combat Trafficking in \\ Persons, 2002 to 2006, John Miller set the office's course as diplomatically aggressive and \\ programmatically creative. He made the annual Trafficking in Persons report more than a bureaucratic \\ submission, putting daring heroes at the center, and insisting on compelling field reporting. He humbly \\ deferred to experts: Survivors, activists, and NGOs living on air, working around the world to confront the \\ trafficking phenomenon in its innumerable guises. He consulted them regularly. Their knowledge became \\ his wisdom.
}

\section{Keywords}

Ambassador John R. Miller, abolitionist, United States, Department of State, trafficking in persons, human trafficking, Sonagachi Project, Bill and Melinda Gates Foundation, Columbia, Japan, entertainment visas, Ansar Burney, camel jockeys, Trafficking in Persons Report, The Netherlands, legal prostitution, Scooter Libby, India, Deputy Secretary of State Robert Zoellick, Secretary of State Condoleezza Rice, National Security Presidential Directive 22, anti-prostitution pledge

\section{Creative Commons License} c) (i) $९$

This work is licensed under a Creative Commons Attribution-Noncommercial-No Derivative Works 4.0 License.

\section{Acknowledgements}

Dignity thanks the following people for their assistance in the preparation of this editorial: Lily Lachapelle, psychology and gender and women's studies majors and Arabic minor, and Doriana Magliocchi, psychology major and gender and women's studies minor, University of Rhode Island. 


\section{DIGNITY}

Volume 2, Issue 4, Article 11, 2017
A JOURNAL ON

SEXUAL EXPLOITATION

AND VIOLENCE

\title{
REMEMBERING AN ABOLITIONIST
}

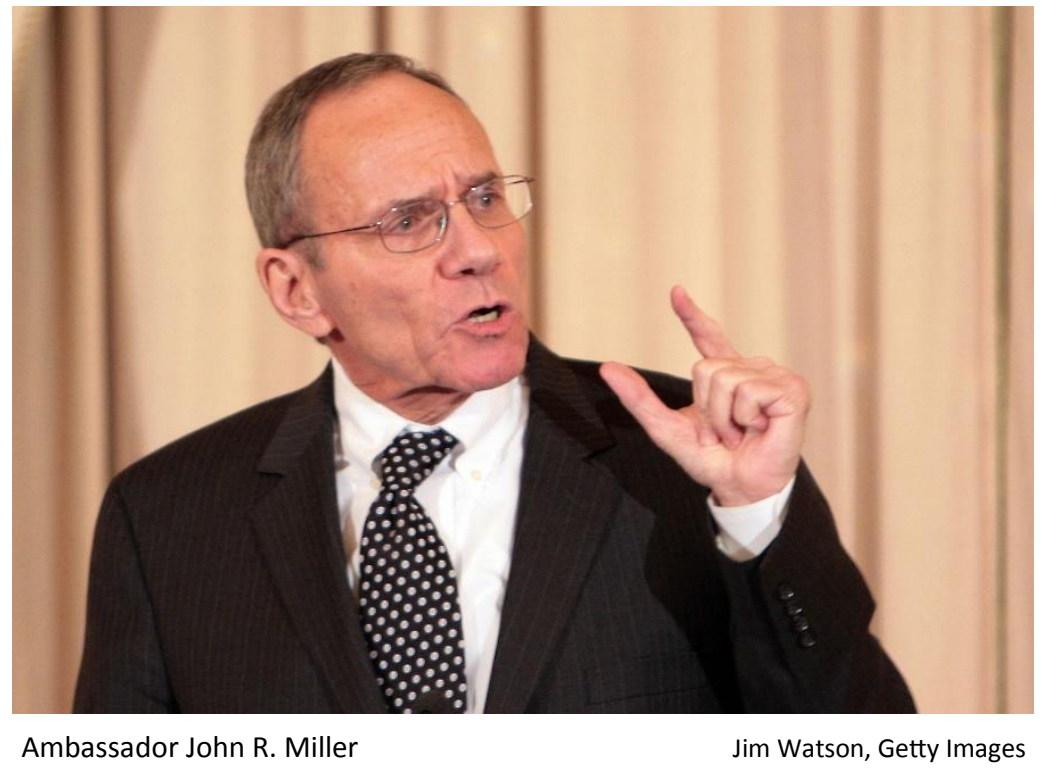

\section{AMBASSADOR JOHN R. MILLER \\ (MAY 23, 1938 - OCTOBER 4, 2017)}

\author{
Eleanor Kennelly Gaetan \\ Frontline Reports Editor, Dignity \\ Donna M. Hughes \\ Editor-in-Chief, Dignity
}

\begin{abstract}
A memorial for Ambassador-at-Large to Monitor and Combat Trafficking in Persons, John R. Miller (May 23, 1938-October 4, 2017). Ambassador Miller believed modern-day slavery, encompassing sex trafficking and forced labor, requires a principled global offensive that the United States is morally obligated to lead. In the four formative years he led the State Department's Office to Monitor and Combat Trafficking in Persons, 2002 to 2006, John Miller set the office's course as diplomatically aggressive and programmatically creative. He made the annual Trafficking in Persons report more than a bureaucratic submission, putting daring heroes at the center, and insisting on compelling field reporting. He humbly deferred to experts: Survivors, activists, and NGOs living on air, working around the world to confront the trafficking phenomenon in its innumerable guises. He consulted them regularly. Their knowledge became his wisdom.
\end{abstract}




\section{KEYWORDS}

Ambassador John R. Miller, abolitionist, United States, Department of State, trafficking in persons, human trafficking, Sonagachi Project, Bill and Melinda Gates Foundation, Columbia, Japan, entertainment visas, Ansar Burney, camel jockeys, Trafficking in Persons Report, The Netherlands, legal prostitution, Scooter Libby, India, Deputy Secretary of State Robert Zoellick, Secretary of State Condoleezza Rice, National Security Presidential Directive 22, anti-prostitution pledge

A ngular and awkward, Ambassador John R. Miller looked like Abraham Lincoln. More than appearance, he shared the sixteenth president's conviction that servitude is unacceptable. Mr. Miller believed modern-day slavery, encompassing sex trafficking and forced labor in his lexicon, requires a principled global offensive that the United States is morally obligated to lead.

In the four formative years he led the State Department's Office to Monitor and Combat Trafficking in Persons, 2002 to 2006, John Miller set the office's course as diplomatically aggressive and programmatically creative. He made the annual Trafficking in Persons report more than a bureaucratic submission, putting daring heroes at the center, and insisting on compelling field reporting.

He humbly deferred to experts: Survivors, activists, and NGOs living on air, working around the world to confront the trafficking phenomenon in its innumerable guises. He consulted them regularly. Their knowledge became his wisdom.

But John Miller was more than merely great at a demanding job. He applied himself with a certitude that was titanic. He sought justice with a forcefulness that was Talmudic.

He used all the connections reaped from years of public service (Seattle City Council, 1972-1979; U.S. Congress, 1985-1993) on behalf of constituents trapped in mills and factories, on farms and fishing vessels, and in brothels worldwide. The movement to end human trafficking was intensely personal for Mr. Miller.

Anti-trafficking activists introduced me, Eleanor Kennelly Gaetan, to Mr. Miller in 2002 while my family was on home leave from USAID/Bucharest where I served as a democracy officer with human trafficking in my portfolio. He was new to the State Department and wanted to hire people who knew the federal government and understood the trauma experienced by trafficking survivors. My family uprooted and reconfigured itself so I could join the State Department's Trafficking in Person's (TIP) office under Mr. Miller's leadership. A few stories exemplify his unusual, and effective, modus operandi.

\section{Sonagachi Red Light Area, Kolkata, India}

In 2004, the U.S. Consulate in Kolkata alerted the TIP office that Indian police trying to rescue children captured in brothels were attacked by a group of women associated with the Sonagachi Project, supported by the Bill and Melinda Gates Foundation ("Gates Foundation takes tips from sex workers", 2004).

The TIP office tried to reach foundation staff in India to explain how counterproductive its program was. We couldn't seem to break through to Gates deciders.

So, John Miller flew to Seattle to meet an old friend, Bill Gates Sr., to explain that condom distribution and education programs intended to "empower" women 
had created a union maintaining the brothel status quo, enslaving minors who brought in the most money. The Gates program was unintentionally protecting traffickers.

Soon after, the Gates Foundation notified the TIP office it would no longer fund the Sonagachi project.

\section{Entertainment Visas}

Smaller countries began contacting the TIP office about transnational trafficking they felt powerless to stop.

Mr. Miller learned from Colombian officials that young women were trafficked to Japan, ostensibly to perform but instead manipulated into prostitution. So, he went to Tokyo to investigate, and consulted other source countries, including the Philippines. Mr. Miller discovered that "entertainment visas" were wildly overused; they often amounted to a cover for trafficking schemes (Head, 2005).

Working with political leaders he knew in Japan's Liberal Democratic Party, Mr. Miller urged Japan to close the visa loophole, which it did. In two years, the number of entertainment visas given to women traveling from the Philippines to Japan, for example, fell from 60,000 to 8,000.

\section{Camel Jockey Trafficking}

By making himself available to activists, Mr. Miller frequently received tips on criminal activity. A remarkable Pakistani lawyer, Ansar Burney, brought hours of secretly recorded video that showed young boys on desert farms in the United Arab Emirates (UAE), trained to race camels for sport. The boys were trafficked primarily from Sudan, India, Pakistan, and Bangladesh.

Mr. Miller worked on multiple fronts-from the U.S. Embassy in Abu Dhabi to DC-based lobbyists employed by the UAE government-to convince the sheiks in charge that exploiting these boys was against international law and against national interest.

Within a few years, not only did the UAE begin using robot jockeys instead of children, the government spent significant money seeking to reunite the camel boys with their families (Boddington, 2017).

\section{The Netherlands: "Super Pimp"}

The Trafficking Victims Protection Act (TVPA) of 2000, which created the TIP office and the annual Trafficking in Persons Report, and the United Nations' Palermo Protocol describe labor slavery and sex trafficking as the two components of human trafficking. The office worked on both kinds of trafficking (unsurprisingly, we found women trafficked in labor schemes were typically sexually exploited as well), but John Miller was particularly angry about countries with legal prostitution regimes because they enlarge the demand for commercial sex, which fuels sex trafficking.

On a visit to The Netherlands, which legalized prostitution in 2000, Miller called the government a "Super Pimp," which made headlines. In response, the U.S. Embassy in The Hague complained to the TIP office that Ambassador Miller was not using "cleared" remarks. This dissatisfaction was channeled up to the seventh floor-where the Secretary of State works. 
When I called Mr. Miller to tell him his "Super Pimp" remark had generated negative attention, he boisterously replied, "Good. I'll say it again!"

For episodes like that, Mr. Miller was considered "a cowboy" in the words of a White House personnel officer. Instead of shying away from officials who thought he took his mission too seriously, he insisted on getting in their faces.

\section{Slavery's "Ground Zero"}

He asked me one afternoon to join him for a meeting at the Vice President's office. I had real trouble picturing Dick Cheney as an ally, since he was occupied running a disastrous war. We were ushered into an office where Cheney's Chief of Staff, Scooter Libby, sat. Ambassador Miller jumped into a diatribe on the lack of anti-trafficking enforcement in India, a country he called the "Ground Zero for global slavery."

Libby was still as a lizard. He didn't say ten words. I could almost hear him thinking, "Get this guy out of my office!" Few decision makers wanted to take on India, which caused Ambassador Miller to press his case that India deserved Tier 3 status in the TIP Report rankings. In 2006, the dispute got particularly acrimonious when the Near East \& Asia Bureau (NEA) pushed back hard.

The Deputy Secretary of State typically decides major TIP Report disputes. When Ambassador Miller discovered Deputy Secretary of State Robert Zoellick was siding with NEA (against Tier 3), he went to Condoleezza Rice's office and sat there until he got in. He said he would resign if she didn't review the decision memo. She did, and she too decided against India's Tier 3 downgrade.

John Miller resigned a few months later.

\section{Policy Legacies}

An obituary in National Review by one of Mr. Miller's longtime friends emphasized how frustrated he got with the bureaucracy (Weigel, 2017). He did, yet he also mastered it and left behind enduring policies. Three in particular deserve to be highlighted.

National Security Presidential Directive 22 (NSPD-22) states that sex trafficking and prostitution are inexplicably linked because all victims of sex trafficking are exploited in prostitution, where violence and coercion are ubiquitous. From this policy (and as required by Congress in a TVPA reauthorization) it followed that no U.S. program or funds should be used to promote prostitution as employment. NSPD-22 remains in force today.

The TIP office and USAID had to decide how to operationalize NSPD-22 and related congressional mandates, in grant agreements. John Miller concluded that grantees could be directed not to promote prostitution with anti-trafficking funds, but grantees could not be required, as an organization, to take such a stand, mainly due to First Amendment considerations.

But USAID adopted a policy requiring organizations to embrace an anti-prostitution policy-known as a "gag rule." Some NGOs took a case against USAID all the way up to the Supreme Court, and won in 2013. Miller's more pragmatic solution was the successful approach. His guidance has been incorporated into hundreds of federal agreements. 
As chair of the interagency Senior Policy Operating Group (SPOG), Ambassador Miller helped coordinate anti-trafficking policy across the federal government. He was very proud of encouraging the Department of Defense (DOD) to adopt a zero-tolerance policy for buying commercial sex. DOD amended the Uniform Code of Military Justice so soldiers guilty of solicitation could get jail time and a dishonorable discharge (Jontz, 2004). Training on human trafficking became mandatory for all branches of the armed services.

I, Donna M. Hughes, had the opportunity to work with Ambassador Miller while he was director of the TIP Office. Later, the U.S. Congress upgraded his authority via the Trafficking Victims Protection Reauthorization Act (TVPRA) of 2003 and his title changed to Ambassador-at-Large to Monitor and Combat Trafficking in Persons.

When he took the job, he didn't know a lot about human trafficking, but he was a fast study. Before he started the job, I gave him background information about human trafficking and the current political debates, such as proposed legalization of prostitution, which some anti-trafficking advocates supported.

John Miller was a highly ethical person dedicated to civil and human rights. He immediately grasped the wrongness and the depths of the human rights violations in human trafficking. I recall attending a Congressional hearing where Ambassador Miller testified about the nature of sex trafficking. He said, and I paraphrase, if the victim didn't consent to the sex act, then every act of sex is rape! His strong moral center enabled him to see the essence and horror of this violation and name it for what it was. He didn't evocate or get tangled-up in debates about agency, choice, and consent.

He also did his own fact-checking. I had briefed him about the ongoing debate about legalization of prostitution within the anti-trafficking movement, and indicated a few people who were advocating for legalization. Like a number of other conservatives in the Bush administration, Ambassador Miller had a hard time believing there were actually reputable people advocating for legalization of prostitution. He later told me that he had a meeting with one of the people I had told him was an advocate of legalization. He said he asked her directly if she supported legalization. He said she admitted that she did. I still remember him rubbing his chin in disbelief that there were anti-trafficking advocates that supported legalization of such a harmful activity.

Ambassador Miller worked with Congress to add a provision to the TVPA reauthorization of 2005 requiring evaluations of what countries were doing to combat "the demand" for victims of sex trafficking to the annual TIP Report. He commissioned me to write two reports on "the demand." I believe this was the first action the U.S. government took to implement anti-demand policies.

After he left the State Department, Mr. Miller continued anti-trafficking activism as a board member for Hunt Alternatives' Demand Abolition project, founded by his cousin Ambassador Swanee Hunt Alternatives, a family philanthropy founded by his cousin Ambassador Swanee Hunt. He helped shape a new program, Demand Abolition, combatting sex trafficking through primary prevention, namely encouraging local law enforcement to focus all its intervention on sex buyers and ending the arrest of prostituted people.

Having witnessed the enduring pain suffered by sex trafficking survivors, John Miller became most committed to legal strategies that prevent harm. 
May he rest in eternal peace.

\section{ACKNOWLEDGMENTS}

Dignity thanks the following people for their assistance in the preparation of this editorial: Lily Lachapelle, psychology and gender and women's studies majors and Arabic minor, and Doriana Magliocchi, psychology major and gender and women's studies minor, University of Rhode Island.

\section{AUTHOR BIOGRAPHIES}

Eleanor Kennelly Gaetan, Ph.D., is the senior legislative advisor for the Coalition Against Trafficking in Women (CATW). She served as Senior Coordinator for Public Outreach at the State Department's Office to Monitor and Combat Trafficking in Persons (2003-2009) and worked at the U.S. Agency for International Development in Romania (2000-2003).

Donna M. Hughes, Ph.D., (Orcid.org/0000-0002-6563-2573) is the editor-inchief of Dignity: A Journal of Sexual Exploitation and Violence. She is a professor of gender and women's studies and criminology and criminal justice, and holds the Eleanor M. and Oscar M. Carlson Endowed Chair in Women's Studies, at the University of Rhode Island.

\section{RECOMMENDED CITATION}

Gaetan, Eleanor Kennelly and Hughes, Donna M. (2017). Dignity: A Journal of Sexual Exploitation and Violence. Vol. 2, Issue 4, Article 11.

DOI:10.23860/dignity.2017.02.04.11. Available at

http://digitalcommons.uri.edu/dignity/vol2/iss4/11.

\section{REFERENCES}

Boddington, Paula. (2017, January 3). Case study: Robot camel jockeys. Yes, really. Ethics for Artificial Intelligence. Retrieved October 18, 2017, from https://www.cs.ox.ac.uk/efai/2017/01/03/robotcameljockeys/

Gates Foundation takes tips from sex workers. (2004, January 27). The Times of India. Retrieved October 18, 2017, from https://timesofindia.indiatimes.com/city/kolkata/Gates-Foundation-takes-tipsfrom-sex- workers/articleshow/446070.cms

Head, Jonathan. (2005, March 15). Japan curbs 'entertainment vias.' BBC News, AsiaPacific. Retrieved October 18, 2017, from http://news.bbc.co.uk/2/hi/asiapacific/4349555.stm

Jontz, Sandra. (2004, September 23). Under DOD plan, soliciting prostitute would be a career-ending defense. Stars and Stripes. Retrieved October 18, 2017, from https://www.stripes.com/news/under-dod-plan-soliciting-prostitute-would-bea-career-ending-offense-1.24409\#.WedZGI6Y6Rw

The White House. National Security Presidential Directive- 22. (2002, December 16). Retrieved October 18, 2017, from http://www.combattrafficking.army.mil/documents/policy/NSPD-22.pdf 
Gaetan and Hughes: Remembering An Abolitionist, Ambassador John R. Miller

Weigel, George. (2017, October 6). Remembering Congressman John Miller. National Review. Retrieved October 18, 2017, from

http://www.nationalreview.com/article/452388/john-miller-obituary 